\title{
Perceptions Of Sustainable Marketing Management By Export Companies In Serbia
}

\author{
Article history \\ Received: 02 June 2013 \\ Sent for revision: 28 June 2013 \\ Received in revised form: 10 July 2013 \\ Accepted: 10 July 2013 \\ Available online: 11 July 2013
}

\begin{abstract}
The present research paper deals with perceptions of sustainable marketing management in the strategies of export companies in Serbia. The objectives in this paper are manifold. They are to emphasize the importance of green marketing management in export activities of domestic companies which pursue their green management plan; to evaluate the company's share in specific marketing segments, and to highlight the significance of successful green marketing management in modern business. Domestic green-oriented companies, which export their products to many different countries, look into the possibility of increasing their sales volumes. The findings in the paper support the hypotheses that domestic companies are perceptive of sustainable marketing issues in their business activities, and sustainable marketing management is becoming an important factor in business activities of modern companies.
\end{abstract}

Key Words: Market segmentation; Perception; Marketing; Management; Export

\section{Percepcije izvoznih preduzeća u Srbiji o održivom marketing menadžmentu}

Apstrakt: Ovaj rad govori o percepcijama održivog marketing menadžmenta u strategijama izvoznih preduzeća u Srbiji. Ciljevi u ovom radu su višestruki. Oni naglašavaju važnost ekološkog marketing menadžmenta u izvoznim aktivnostima domaćih preduzeća koja realizuju svoje planove ekološkog mena-

\footnotetext{
${ }^{1}$ Singidunum University, Faculty of economics, finance and administration Belgrade, zcajka@gmail.com

${ }^{2}$ Educons University, Faculty of Business Economy, Novi Sad, e-mail: bmasic@singidunum.ac.rs
} 
Čajka Z. et al.: Perceptions Of Sustainable Marketing Management By Export...

džmenta. Cilj rada jeste takođe da se oceni učešće preduzeća u odgovarajućim segmentima ekološkog marketinga, kao i da se naglasi važnost uspešnog ekološkog marketing menadžmenta u savremenom poslovanju. Domaća ekološka preduzeća koja su izvozno orijentisana sagledavaju mogućnost povećanja obima prodaje. Dobijeni rezultati u ovom radu potvrđuju hipoteze da su domaća preduzeća svesna održivosti u svom poslovanju i da održivi marketing menadžment postaje važan faktor u poslovnim aktivnostima savremenih preduzeća.

Ključne reči: segmentacija tržišta , percepcije , marketing , menadžment, iZVOZ

\section{Introduction}

The present research paper represents a part of the research conducted for the writing of a doctoral dissertation submitted to the Faculty of Economics, Finance and Administration (FEFA) of Singidunum University, Belgrade, in fulfillment of the requirements for the degree of $\mathrm{PhD}$ in Marketing Management in 2013.

Since there is scanty literature on green marketing management in our country, the present research paper represents an attempt to provide an indepth analysis of green marketing management. The paper also contributes a deeper understanding of green marketing management, taking into account all of its important characteristics, like marketing mix, consumer behavior, competition and green marketing strategies. This paper is an original research conducted in the insufficiently explored field of green marketing in Serbia.

In the last decade manufacturers and consumers are being directed towards green products and services on a larger scale. Ecological factors are fast becoming the main focus in marketing. Changes in the way of consumption are equally important as changes in production processes. Consumers are becoming aware of the dependence between air pollution, soil degradation and chemical contamination, and also between factors such as food, clothes, transport and dwelling. Preservation and environmental protection represent a challenge for the industry in general. Many marketing experts maintain that green marketing will represent an integral part of all business activities in the course of this century. Thus, grave concern for the environment in which we live appears to be an integral part of the practice of marketing management.

The environment in which we live is very complex and production, distribution and buying of green products represent major challenges for both producers and buyers. The producers are constantly striving to find new technologies in the production of safe and healthy foods, while the consumers are in the 
never-ending process of receiving reliable and all-embracing information about green products.

Today, in the world and in our country, green marketing becomes an unavoidable subject matter in academic treaties and in companies' business activities.Thus, the significance of research and analyses of green marketing has become of utmost importance in theory and practice of modern business activities.

Marketing has an important leadership role to play within companies in relation to the environment. Čajka (2005) points out that „firms engaged in the greening process should strive to promote corporate social and environmental improvement" (p. 24). Commitment to a complete greening of the company is of overwhelming significance for every green organization.

Today we are faced with a current wave of green opportunities and the sale of new products and services. According to Phyper and MacLean (2009:12), the following issues drive this wave of opportunities: increasing amount and complexity of governmental legislation related to environmental issues, consumer demand for green products and services, demand for renewable energy and clean water, and greening of the boardroom.

The interdependence between global environmental protection and global economy is becoming more obvious and more definite. Marketing cannot be separated from the environmental protection. The role of marketing in sustainable development has become of great importance. Many domestic companies are becoming aware of ecological imperative to which marketing must respond in the very near future. In actuality, researches of this kind are becoming of primary importance in our conditions. Management of domestic companies is aware of the importance of the quality of raw materials which will be used in production processes. The effect of consumption on human life and biosphere has also become of importance to the management. Sustainable development needs sustainable marketing.

Serbian companies must define the concept of green marketing. The implementation of the strategies of green marketing represents an important segment in business activities, both in home and foreign markets. Companies which export their products or services should apply adequate standards which are widely applicable in modern green marketing.

\section{Aims and Hypotheses}

This research paper has the aim to test perceptions of sustainable marketing management in export-oriented companies in Serbia and to analyze company's share in specific marketing segments. The aim is also to evaluate the 
Čajka Z. et al.: Perceptions Of Sustainable Marketing Management By Export...

existing motives in order to decide on the suitable green marketing strategy in export business, and to highlight the significance of successful green marketing management in modern business.

On the basis of the defined aims, the present research paper should test the following hypotheses:

Hypothesis 1) Domestic companies are perceptive of sustainable marketing issues in their business activities;

Hypothesis 2) Sustainable marketing management is becoming an important factor in business activities of modern companies.

\section{Methodology}

An appropriate scientific literature was used in research, and the instrument of research was based on previous qualitative research. In order to test the stated hypotheses, a sample of 75 small and medium-sized enterprises was identified in various domestic business journals and magazines. Besides that, websides of Serbian Chamber of Commerce, Belgrade Chamber of Commerce and many other regional chambers were used. Several large manufacturing companies have been contacted online. The present research is mainly based on the responses to online questionnaires. Besides online questionnaires, we have used telephone interviews and other secondary sources of data, such as Serbian specialized magazines »Economist«, „Economic Policy«, »Economic Themes«, »Ecology«, etc.

Figure 1. Company Orientation

Is the company oriented towards home trade or export?

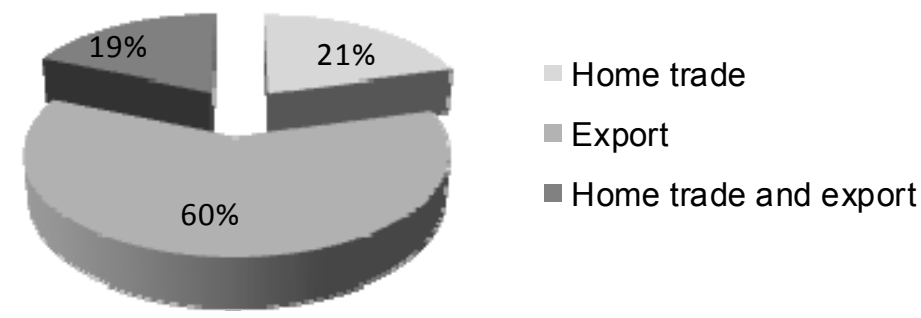


Čajka Z. et al.: Perceptions Of Sustainable Marketing Management By Export...

In the analysis of this paper, there are data collected from domestic companies which have or have not introduced green marketing management in their business activities. However, it was not easy to identify a company which was oriented towards green marketing. Here, we have companies which have not publicly demonstrated the use of green strategies, and because of this it was difficult to identify such companies. Various questionnaires have been sent to a definite number of companies. Later, we contacted persons in charge of a response. We have also conducted many interviews with persons who were ready to meet the interviewers.

Two thirds of the contacted companies responded to our questionnaires. One third of them were unready to participate in the project.

Forty-eight companies took part in our research. Ten companies were engaged in home trade, 29 were export companies and 9 companies were engaged both in export and home trade (Fig.1). We have distributed 6 questionnaires with a set of questions in them (Perceptions of Sustainable Marketing in Business Activities, Company's Share in Specific Marketing Segments, Company Data, Responsibility of the Company to Sustainability, Marketing and Distribution, Production and Use of Raw Materials).

In this research paper, are main focus will be on perceptions of sustainable marketing in business activities of domestic export companies and companies' share in specific marketing segments. We have used a Chi-squared test with realised and expected frequencies. The research was conducted in the period of May 2009 until March 2010.

We have used the following statistical methods:

- Descriptive statistics for description of data

- Frequency distribution

- Chi-squared test

We have used Excel programme in the data analyses. The analyses were done with the probability of $95 \%(p<=0,05)$. The analysed data and results were shown in Tables 1, 2, 3, and 4.

Table 1.The use of Chi-squared test for question No. 1: Which of the following alternatives applies your company? (Questionnaire No.6: Company's share in specific marketing segments)

\begin{tabular}{|c|c|c|c|c|c|}
\hline $\begin{array}{c}\text { Realized } \\
\text { Frequences }\end{array}$ & 13 & 15 & 23 & 10 & 7 \\
\hline $\begin{array}{c}\text { Expected } \\
\text { Frequences }\end{array}$ & 13.6 & 13.6 & 13.6 & 13.6 & 13.6 \\
\hline
\end{tabular}

$p$-value $=0.0286$ 
Čajka Z. et al.: Perceptions Of Sustainable Marketing Management By Export...

On the level of importance of $5 \%$, we can state that statistically there is significant difference between grade points for the analyzed questions.

Table 2-The use of Chi-squared test for question No 2: Which of the following alternatives do you think can attract consumers to buy your product? (Questionnaire No.6: Company's share in specific marketing segments)

\begin{tabular}{|c|c|c|c|c|c|}
\hline $\begin{array}{c}\text { Realized } \\
\text { Frequences }\end{array}$ & 24 & 19 & 21 & 21 & 10 \\
\hline $\begin{array}{c}\text { Expected } \\
\text { Frequences }\end{array}$ & 19 & 19 & 19 & 19 & 19 \\
\hline
\end{tabular}

$p$-value $=0.1991$

On the level of importance of $5 \%$, we can state that statistically there is no significant difference between grade points for the analyzed questions.

Table 3-The use of Chi-squared test for question No. 3: Which of the following alternatives means higher prices in comparision with traditional products?

(Questionnaire No.6: Company's share in specific marketing segments)

\begin{tabular}{|c|c|c|c|c|c|}
\hline $\begin{array}{c}\text { Realized } \\
\text { Frequences }\end{array}$ & 20 & 16 & 9 & 9 & 16 \\
\hline $\begin{array}{c}\text { Expected } \\
\text { Frequences }\end{array}$ & 14 & 14 & 14 & 14 & 14 \\
\hline
\end{tabular}

$\mathrm{p}$-value $=0.1518$

On the level of importance of $5 \%$, we can state that statistically there is no significant difference between grade points for the analyzed questions.

Table 4-The use of Chi-squared test for question No. 4: Which of the following alternatives means higher costs for your company? (Questionnaire No.6:

Company's share in specific marketing segments)

\begin{tabular}{|c|c|c|c|c|c|}
\hline $\begin{array}{c}\text { Realized } \\
\text { Frequences }\end{array}$ & 21 & 17 & 12 & 16 & 13 \\
\hline $\begin{array}{c}\text { Expected } \\
\text { Frequences }\end{array}$ & 15.8 & 15.8 & 15.8 & 15.8 & 15.8 \\
\hline
\end{tabular}

p-value $=0.5225$

On the level of importance of $5 \%$, we can state that statistically there is no significant difference between grade points for the analyzed questions. 
Čajka Z. et al.: Perceptions Of Sustainable Marketing Management By Export...

\section{Results and Discussion}

On the basis of the analysed information and data about perceptions of sustainable marketing in business activities and company's share in specific marketing segments, we have obtained the following results:

Table 5. Perceptions of Sustainable Marketing in Business Activities

\begin{tabular}{||l|c|c||}
\hline & YES & NO \\
\hline $\begin{array}{l}\text { Sustainable marketing cares about environmental protecti- } \\
\text { on and it bears the responsibility for the development and } \\
\text { growth of business activities. According to this definition, } \\
\text { do you believe that your company applies sustainable mar- } \\
\text { keting? }\end{array}$ & $62 \%$ & $38 \%$ \\
\hline $\begin{array}{l}\text { Is your company ethically responsible towards environ- } \\
\text { ment? }\end{array}$ & $65 \%$ & $35 \%$ \\
\hline $\begin{array}{l}\text { Is your company faced with the market pressure to offer } \\
\text { green products? }\end{array}$ & $60 \%$ & $40 \%$ \\
\hline $\begin{array}{l}\text { Did your company enter foreign markets because it applied } \\
\text { sustainable marketing? }\end{array}$ & $42 \%$ & $58 \%$ \\
\hline $\begin{array}{l}\text { Does sustainable marketing mean that your company achi- } \\
\text { eves higher profit margin? }\end{array}$ & $54 \%$ & $46 \%$ \\
\hline $\begin{array}{l}\text { Does sustainable marketing mean higher prices of your } \\
\text { products? }\end{array}$ & $60 \%$ & $40 \%$ \\
\hline $\begin{array}{l}\text { Does sustainable marketing mean higher costs in your } \\
\text { business activities? }\end{array}$ & $56 \%$ & $44 \%$ \\
\hline
\end{tabular}

Based on our research, $62 \%$ of the domestic companies provided a positive answer to the definition of sustainable marketing (see Table 5). Sixty-five percent of the companies is ethically responsible towards environment. Fortysix percent of the interviewed companies does not think that sustainable marketing helps them achieve higher profit margin. Also, $56 \%$ of the companies claimed that sustainable marketing meant higher costs in their business activities. In literature, it is known that green products can increase profit margin. Serbian companies should use the opportunity and try to increase profit margin by producing green or sustainable products. There are three stages which could be employed to realize the growth of profit margin. Firstly, the characteristics and values of green products should be visible and evaluated by everyone in the value chain. Willingness to pay more on the part of the consumer depends on how he or she perceives the product. If the consumer derives satisfaction from the product, then the company should make use of it and 
try to convince the consumer to buy the product or service. In the second stage, an added value of the green product should have a higher price. The challenge lies in the fact that a new price should be set. Many companies are reluctant to set a new higher price, because they are not sure whether the customer is ready to pay more for the product. In the third stage, green products should be offered with traditional or conventional products. Buyers should not be pushed into buying green products. Green products are fast becoming more popular and attractive to consumers.

Green products require more expensive inputs than traditional products. That is why green products are more expensive than traditional products. Green products are in demand, and companies should do their best to respond to the demands of environmentally conscious consumers. Domestic companies should strive to incorporate sustainability into innovation and design in the initial phases of their products, all in the aim to get and retain consumers.

Table 6. Company's Share in Specific Marketing Segments

\begin{tabular}{|l||c|c||c|c||c||}
\hline & $\begin{array}{c}\text { Green } \\
\text { Product }\end{array}$ & $\begin{array}{c}\text { Green } \\
\text { Packa- } \\
\text { ging }\end{array}$ & $\begin{array}{c}\text { Corporate } \\
\text { Sustainable } \\
\text { Practice }\end{array}$ & $\begin{array}{c}\text { Promotion or } \\
\text { advertising of one } \\
\text { of the previously } \\
\text { mentioned alter- } \\
\text { natives }\end{array}$ & Nothing \\
\hline \hline $\begin{array}{l}\text { Which of the following } \\
\text { alternatives applies your } \\
\text { company? }\end{array}$ & $19 \%$ & $22 \%$ & $34 \%$ & $15 \%$ & $10 \%$ \\
\hline $\begin{array}{l}\text { Which of the following } \\
\text { alternatives do you think } \\
\text { can attract consumers to } \\
\text { buy your product? }\end{array}$ & $25 \%$ & $20 \%$ & $22 \%$ & $22 \%$ & $11 \%$ \\
\hline $\begin{array}{l}\text { Which of the following } \\
\text { alternatives means } \\
\text { higher prices in compari- } \\
\text { sion with traditional } \\
\text { products? }\end{array}$ & $28 \%$ & $23 \%$ & $13 \%$ & $13 \%$ & $23 \%$ \\
\hline $\begin{array}{l}\text { Which of the following } \\
\text { alternatives means } \\
\text { higher costs for your } \\
\text { company? }\end{array}$ & $27 \%$ & $22 \%$ & $15 \%$ & $20 \%$ & $16 \%$ \\
\hline
\end{tabular}

Table 6 analyzes company's share in specific marketing segments. Thirty-four percent of the companies claimed that they pursued corporate sustainable practice in their business activities. Green product is the second alternative which can attract prospective consumers (25\%). Twenty-eight percent of the companies claimed that green products raised prices in the market. It is interesting to note that promotion or advertising contributes to higher costs in the company (20\%). Tables 1, 2, 3 and 4 show the use of Chi-squared test for the 
analysis of company's share in specific marketing segments. It is obvious that in most cases there is no significant difference between grade points for the analyzed questions. Only in the question No. 1 (Which of the following alternatives applies your company?), there is significant difference between grade points for the analyzed question.

The concept of green marketing is inadequately researched and analysed (Grant, 2007; Hartman \& Ibanez, 2006; Baker \& Sinkula 2005, and others wrote about it). Olson (2008) wrote that not many companies managed to apply the green marketing concept throughout the organization. This concept allows companies to gain competitive advantage in the market. However, companies are faced with various difficulties in the application of green marketing concept. Not many domestic companies managed to apply this concept in their business activities. Even when companies define their green strategy, they find themselves in a dilemma whether they have chosen and implemented the right strategy. According to Čajka (2013), »the implementation of the appropriate green strategy requires fundamental, all-embracing and integral approach in all marketing activities, including the elements of the marketing mix« (p. 262). Only the companies which are ready to accept and realize the green issues throughout the whole organization, will be in a position to develop and implement green strategies.

There are several green strategies which could be used by a company. They are as follows:

- Green innovation

- Greening the organization

- Green alliances

The first and most widely used strategy is green innovation. By developing new products the company signals its intention to offer a sustainable product or products. Greening the organization is the second green strategy. The most important aspects of this strategy are green issues applicable throughout the company. Production and delivery have important place in this strategy. Green alliances is also an important green strategy. Companies need to form green alliances, because this creates a positive impression upon the employees, stakeholders, and the public.

Many companies in the world pursue green strategies. Serbian companies should learn from foreign companies and try to keep in step with them. Serbian companies should also keep abreast with the latest developments in the field of green marketing practice.

There is no universal strategy which could be convenient and suitable for every company. (Ginsburg \& Bloom, 2004). These authors developed the Green Marketing Matrix, in which four strategies were represented, starting from very passive ones and further on to more visible and aggressive 
ones.The green strategies depend on the size of the market, and also on the capability of the company to differentiate its products on the basis of green properties.

Domestic companies, according to this matrix, mainly represent the group of companies called Lean Green. The companies in this group usually do not make public their ecological initiatives. Their aim is to lower the costs and to engage themselves in various activities of environmental protection. These companies do not gain competitive advantage with green products, but with traditional products. It would be rather difficult for the companies in this group to maintain the overall green initiative. That is why these companies create sporadic green brands, because they are of the opinion that this represents a much surer and safer approach to green products.

The next group of domestic companies apply green strategies, but only as an answer to an action initiated by competition. This is the defensive group of companies. These companies do not spend substantial finances on ecological activities, because they do not want to create high expectations which they would find difficult to fullfil. There are not many domestic companies in this group.

The last group of companies is called extreme ecological companies or ecological entrepreneurs, as defined by Menon and Menon (1997). These companies offer radically new green products or services. Services are based on eco-tourism. The companies in this group offer various agricultural products, cosmetics made by purely natural ingredients, production of organic foods, etc. The production in this group of companies is limited quantatively. That is why $56 \%$ of the companies claimed that sustainable marketing meant higher costs in their business activities. Unfortunately, there are not many extreme green companies in Serbia. These companies integrate ecological processes in their production stages and green products in a complete manner. These companies always strive to meet the toughest ecological standards in production and distribution of their products. It goes without saying that these companies possess all the necessary licences and certificates (ISO 14020, 14021, 14024, 14025).

The data derived from the present research are in contradiction to the international data found in researches from other authors, such as Shi i Kane (1996), Prakash (2002), Ginsburg i Bloom (2004) i D'Souza, et. al. (2006). Firstly, Serbian companies do not use green packaging in high percentage (22\%), while international norms show that this is the most important strategy in green marketing (Čajka, 2013: 265). Green packaging must satisfy the factors of safety and quality of the product. There are many pieces of legislation defining what can be in packaging material, especially related to materials which come in contact with the food. As international trade, Internet sales and the trend towards products with short life spans continue to develop, the volume of 
goods placed on the market has increased enormously and much faster than waste disposal capacity (Phyper and MacLean, 2009). Green packaging is more expensive than conventional or traditional packaging, because green packaging must respond to very strict demands in the material production. For instance, there is a difference in the quality of plastic bottles. Traditional PET (polyethylene terephthalate) bottles are made from fossil fuels, such as naphtha, while eco-bottles are made by a combination of traditional materials and $30 \%$ of ingredients based on plants. There is a growing tendency to increase natural ingredients in the production of eco-bottles. Domestic companies, which specialize in the production of mineral waters and juices, are aware of these trends and they are trying to introduce green packaging (e.g. Rosa, mineral water), although this requires substantial finances for reasearch, design and innovation. According to the responses made by interviewees, packaging costs are still very high. On the basis of international norms, packaging contributes to about $20 \%$ in the overall costs of the product. In Serbia this percentage is even higher.

Packaging, as a marketing tool, is a part of the company's competitive strategy. Traditional marketing mix (product, price, place and promotion) can easily be directed to packaging.

A larger number of foreign companies operating in Serbia would contribute to the dynamic growth of domestic packaging sector. These foreign companies could raise awareness of design and quality of packaging. Green packaging is fast becoming an important factor in the production and promotion of green products. Domestic companies, which produce packaging materials, adhere to various production standards (ISO - International Organization for Standardization 9001, ISO 14000 i HACCP, Hazard analysis and critical control points). There has become a growing need for standardization in product labels and marketing claims.

Further, domestic companies take into account the fact that the price of a green product is higher. Foreign consumers are willing to pay more for green products, while domestic buyers are reluctant to pay more for sustainable products. In times of financial and economic crisis, cheaper traditional products find their way to consumers more easily. Domestic companies are not under pressure to offer green products. The situation is reverse abroad: foreign buyers insist on sustainable products.

In direct contacts with respresentatives of the interviewed companies, we have found out that our companies are not significantly present on foreign markets in which green products are in great demand. That means that our companies are mainly present in neighbouring countries in which green concepts are undeveloped or partially developed, although there are niches which are willing to pay a premium for certain green products which meet strict ecological standards. 
The application of green marketing strategies in foreign markets is one of the most important factors of competitive advantage. Besides innovation and flexibility, small and medium companies, which adhere to green marketing strategies, create a bigger competitive advantage than non-green companies. In Serbia, small and medium companies comprise about $99 \%$ of all domestic companies with more than two-thirds of all the employed people.

The competition among green companies is on the increase. Four factors determine the competitive focus and possible source of competitive advantage. According to Orsato (2006: 130-131), the factors are as follows:

- $\quad$ The structure of the industry in which the company operates;

- $\quad$ The position of the company within the industry;

- The types of markets in which the company operates;

- The company's capabilities.

On the basis of the overall analysis, $34 \%$ of the interviewed companies stated that corporate sustainable practice represents one of the alternatives used in company's business activities. It is the truth universally acknowledged that companies, which employ modern management strategies, have an important role in the solution of environmental problems. Today,environmental activities of companies are closely monitored by the government and the public, and with the accesion of Serbia to the European Union, the pressure will bececome even greater. Serbian companies will have to respond to environmental challenges, not only in export activities, but also in home market.

\section{Conclusion}

Going green is viewed as an unavoidable strategic choice for domestic companies. This is also an answer to an increased public pressure on companies to accept clear ethical standards and responsibility in business operations. Greening the organization at all levels of business activities has become of vital importance for accountable companies. Organizations which consider environmental issues in their business should gain a competitive advantage on both home and foreign market. New sustainable standards and concerned consumers will demand responsibility from companies in their green marketing efforts. Serbian companies should more readily adapt themselves to numerous and unpredictable challenges on dynamic and unpredictable international markets.

In this paper we have confirmed that domestic companies are perceptive of sustainable marketing issues in their business activities and that sustainable marketing management is becoming an important factor in business activities of modern companies. Domestic green-oriented companies, which export 
their products to many different countries, look into the possibility of increasing their sales volumes. A high quality product is a guarantee that an export company will keep an image of a reliable supplier and it will secure a longstanding presence on the market. In our country, there are not many green companies, but they are striving to perceive that their competitive advantage lies at the cutting-edge of the green shift.

\section{References}

Čajka, Z. (2013) „Ecological Marketing Management in the Strategies of Export Companies in Serbia" [Ekološki marketing menadžment u strategijama izvoznih preduzeća u Srbiji]. Unpublished doctoral dissertation (Singidunum University Faculty of Economics, Finance and Administration - FEFA), pp.1 - 339.

Čajka, Z. (2005) »Environmental Marketing in the New Millennium«, Ecologica, 12 (2005), special edition, No 10, pp. 21-26, Belgrade.

D'souza, C., Taghian, M., Lamb, P., \& Peretiatkos, R. (2006). Green products and corporate strategy: an empirical investigation. Society and Business Review, 1(2), 144-157. doi:10.1108/17465680610669825

Ginsburg, Jill Meredith \& Bloom, Paul (2004) Choosing the Right Green Marketing Strategy. MIT Sloan Management Review, 46(1), pp.77-84.

Grant, J. (2007) "Green Marketing Manifesto". John Wiley and Sons, England

Menon, A., \& Menon, A. (1997). Enviropreneurial Marketing Strategy: The Emergence of Corporate Environmentalism as Market Strategy. Journal of Marketing, 61(1), 51-67. doi:10.2307/1252189

Olson, E. (2008) »Better Green Business: Handbook for Environmentally Responsible and Profitable Business Practices«, Wharton School Publishing, Upper Saddle River, New Jersey, USA.

Orsato, R. (2006) »Competitive Environmental Strategies: When does it pay to be green?« California Management Review, 48(2)

Phyper, J.D. \& MacLean, P. (2009) Good to Green, Wiley, Mississauga, Ontario

Prakash, A. (2002). Green marketing, public policy and managerial strategies. Business Strategy and the Environment, 11(5), 285-297. doi:10.1002/bse.338

Shi, J. Stephen \& Kane, Jane (1996). Green Issues. Business Horizons, 39(1), pp.6570. 